\title{
Metode Pinhole Model untuk Menentukan Jarak Perpindahan Kendaraan dalam Video
}

\author{
Rizki Yusliana Bakti ${ }^{* 1}$ \\ ${ }^{1}$ Program Studi Informatika Fakultas Teknik Universitas Muhammadiyah Makassar \\ e-mail: rizkiyusliana@unismuh.ac.id
}

\begin{abstract}
Intelligent Transportation System is a solution to overcome the problem of transportation. The purpose of this study was to design a system to calculate the distance of vehicle movement in the video. One example of application of intelligent transport system is to calculate the speed of a vehicle that can be used in traffic engineering. Parameters used to obtain the speed of the vehicle is the distance parameter. The distance of vehicle movement in the video can be obtained by using a pinhole camera calibration model. An appropriate calibration of camera can provide the intended parameter. There are several stages to perform calculation of the distance of object movement. The first stage was a detection of vehicle within the frame. The detection was required to obtain the center point of vehicle object. The next stage was to detect an object within the frame. This was performed to understand the movement of object from one frame to another frame. The data used for the study were video data with mov format. The result of research showed that the method of pinhole model was applicable to calculate the distance of object movement in video. The application of this method can help in calculating the object distance without manual calculation.
\end{abstract}

Keyword: intelligent transport system; pinhole mode; vehicle detection; camera calibration

\section{Abstrak}

Sistem Transportasi Cerdas merupakan solusi untuk mengatasi masalah transportasi. Tujuan dari penelitian ini adalah untuk merancang suatu sistem menghitung jarak perpindahan kendaraan dalam video. Salah satu contoh aplikasi Sistem Transportasi Cerdas adalah menghitung kecepatan kendaraan yang bisa digunakan dalam rekayasa lalu lintas. Parameter yang perlu diketahui untuk memperoleh kecepatan kendaraan diantaranya adalah parameter jarak. Jarak perpindahan kendaraan dalam video dapat diperoleh dengan menggunakan kalibrasi kamera pinhole model. Dilakukan kalibrasi kamera yang tepat untuk memperoleh parameter - parameter yang dibutuhkan. Ada beberapa tahap yang harus dilakukan untuk menghitung jarak perpindahan objek. Tahap pertama adalah mendeteksi objek kendaraan di setiap frame. Deteksi diperlukan untuk mengetahui titik center point dari objek kendaraan. Tahap selanjutnya adalah melakukan pelacakan objek di setiap frame. Hal ini dilakukan untuk mengetahui perpindahan objek dari frame satu ke frame selanjutnya. Data yang digunakan adalah data video dengan format .mov. Hasil penelitian menunjukkan bahwa metode pinhole model bisa diterapkan untuk menghitung jarak perpindahan objek dalam video. Dengan menerapkan metode ini maka jarak objek bisa dihitung tanpa melakukan perhitungan secara manual.

Kata kunci: sistem transportasi cerdas, pinhole model, deteksi kendaraan, kalibrasi kamera

\section{Pendahuluan}

Seiring berkembangnya pertumbuhan penduduk di Indonesia, maka kebutuhan akan transportasi juga semakin meningkat. Berdasarkan data Korps Lalu Lintas Kepolisian Negara Republik Indonesia pada tahun 2013, jumlah kendaraan mencapai 104.211 juta unit. Untuk kota Makassar, data jumlah kendaraan pada tahun 2013 mencapai 1.160.385 unit. Kondisi ini menimbulkan permasalahan seperti kemacetan yang semakin sulit dicari jalan keluarnya. Untuk mengatasi hal tersebut, dibutuhkan manajemen rekayasa lalu lintas. Aturan mengenai pedoman pelaksanaan kegiatan manajemen dan rekayasa lalu lintas ditetapkan pada PM Nomor 96 tahun 2015. Rekayasa lalu lintas dapat dilakukan dengan mengkaji karakteristik jalan terlebih 
dahulu seperti kecepatan rata-rata, nisbah antara volume dan kapasitas lalu lintas. Intelligent Transport System (ITS) dapat diterapkan sebagai sistem pendukung rekayasa lalu lintas yang memadukan informasi dan fungsi manajemen lalu lintas. Kecepatan kendaraan bisa diperoleh dengan menghitung jarak perpindahan objek disetiap frame video.

Tahap awal yang dilakukan untuk menghitung jarak perpindahan objek dalam gambar adalah deteksi kendaraan. Ada beberapa metode yang bisa digunakan untuk deteksi kendaraan. Metode - metode tersebut antara lain, Optical Flow, Gaussian Mixture Model (GMM), Global Counture Shape dan Histogram of Oriented Gradien [1], [2], [3]. Pada penelitian ini kami menggunakan metode GMM pada tahap deteksi. Metode ini baik digunakan ketika mendeteksi objek bergerak dalam video. Akurasi sistem dapat ditingkatkan dengan menerapkan analisis blob dan menentukan batas area ROI [1]. Tahap selanjutnya yang dilakukan adalah menghitung jarak objek kendaraan disetiap frame. Jarak objek disetiap frame bisa diperoleh dengan menggunakan proyeksi kamera Pinhole Model [4]. Ada beberapa parameter yang dibutuhkan untuk menghitung jarak menggunakan Pinhole Model seperti focal length, frame rate, tinggi kamera dari permukaan tanah, dan resolusi gambar. Parameter parameter tersebut diperoleh dengan melakukan kalibrasi kamera terlebih dahulu [5], [6]. Tahap terakhir adalah menghitung jarak perpindahan kendaraan dalam video. Jarak perpindahan kendaraan diperoleh dengan menghitung selisih jarak kendaraan di frame sekarang dengan frame sebelumnya.

Beberapa penelitian sebelumnya fokus pada deteksi objek dan kalibrasi kamera. Sehingga pada penelitian ini dikembangkan sistem untuk menghitung jarak dalam video yang nantinya bisa digunakan untuk menghitung kecepatan kendaraan dalam video. Tujuan dari penelitian ini adalah untuk merancang suatu sistem menghitung jarak perpindahan kendaraan dalam video.

\section{Metode Penelitian}

Lokasi pengambilan data dilakukan di jalan Jenderal Sudirman Makassar. Data yang digunakan pada penelitian ini merupakan data video kendaraan yang diambil dengan menggunakan kamera DSLR yang diletakkan di atas jembatan penyebrangan orang.

Penelitian ini terdiri dari beberapa tahap yaitu pengambilan data menggunakan kamera yang diletakkan di atas jembatan penyebrangan orang. Selanjutnya dilakukan studi literatur tentang metode yang digunakan. Setelah itu melakukan uji coba sistem dan analisa yang akan digunakan dalam proses pembuatan laporan tahap akhir.

Metode analisis data yang dilakukan pada penelitian ini adalah dengan melakukan pengamatan terhadap besar jarak perpindahan objek kendaraan yang terdeteksi di setiap frame video. Jarak objek kendaraan diperoleh dengan menggunakan kalibrasi kamera pinhole yaitu proyeksi sumbu y untuk melihat pergeseran secara vertical. Selanjutnya dilakukan proyeksi sumbu x untuk melihat pergeseran kendaraan secara horizontal. Selanjutnya jarak perpindahan secara vertical dan horizontal digunakan untuk menghitung jarak perpindahan kendaraan secara diagonal.

\section{Hasil dan diskusi}

Desain sistem dimulai dengan melakukan input data berupa video kendaraan. Selanjutnya objek kendaraan dalam video input akan dideteksi menggunakan metode GMM. Pada tahap ini akan dipisahkan antara objek kendaraan dan bukan kendaraan. Tahap selanjutnya adalah menghitung jarak kendaraan disetiap frame menggunakan metode Pin Hole Model. Tahap terakhir adalah menghitung jarak perpindahan kendaraan yang merupakan selisih jarak di frame sekarang dan frame sebelumnya.

Gambar 1 menunjukkan input data berupa video yang telah dipecah menjadi beberapa frame. Selanjutnya frame - frame ini diolah satu persatu hingga mencapai batas maksimum jumlah frame dalam video. 


\begin{tabular}{|c|c|}
\hline ת & $\begin{array}{l}\text { e-ISSN : } 2686-1917 \\
\text { p-ISSN : } 2657-0653\end{array}$ \\
\hline
\end{tabular}

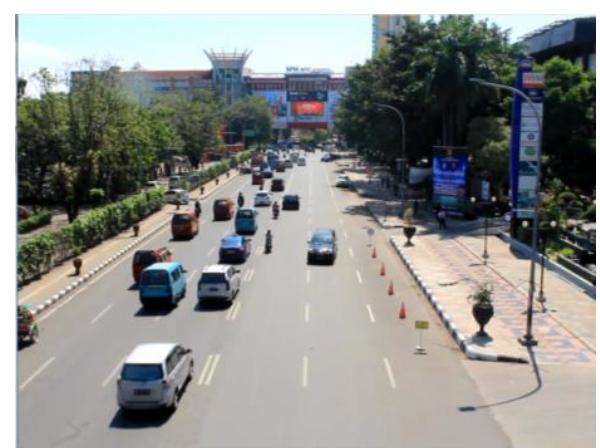

Gambar 1. Input Data

Selanjutnya dilakukan deteksi objek kendaraan menggunakan metode GMM. Pada tahap ini dilakukan segmentasi foreground untuk memisahkan antara objek foreground dan background. Foreground adalah objek bergerak dalam video sedangkan background adalah objek static dalam video. Segmentasi foreground ditunjukkan pada gambar 2.

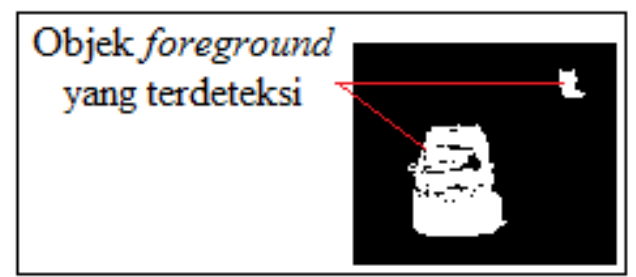

Gambar 2. Segmentasi foreground

Selanjutnya objek yang terdeteksi sebagai foreground akan dibandingkan dengan luasan blob yang telah ditentukan dalam metode GMM. Foreground yang memenuhi batas minimum dan maksimum blob akan dianggap sebagai objek kendaraan. Selanjutnya objek yang terdeteksi sebagai kendaraan ditandai bounding box seperti yang ditunjukkan gambar 3 .

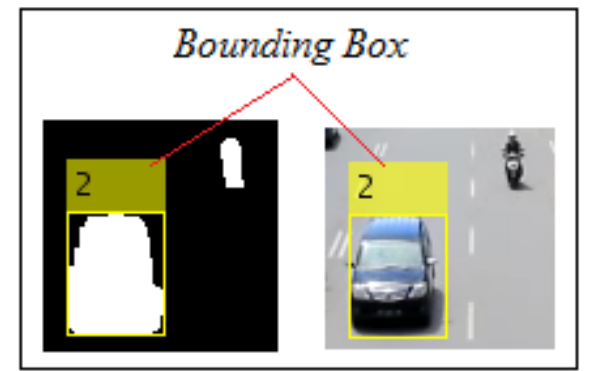

Gambar 3. Objek yang terdeteksi bounding box

Jarak dari objek yang terdeteksi bounding box bisa diperoleh dengan melakukan kalibrasi kamera terlebih dahulu pada saat pengambilan data. Parameter - parameter yang diperoleh dari hasil kalibrasi kamera selanjutnya digunakan untuk menghitung jarak objek yang terdeteksi disetiap frame. Parameter - parameter yang dibutuhkan adalah lebar pixel gambar, panjang pixel gambar, tinggi kamera dari permukaan jalan, focal length (jarak dari bidang gambar ke titik focus), sudut proyeksi gambar, sudut kemiringan kamera, jarak titik letak kamera ke batas bawah gambar, dan posisi pixel objek pada gambar. Setelah diperoleh jarak perpindahan objek disetiap frame, maka selanjutnya dilakukan perhitungan jarak perpindahan objek. Jarak perpindahan objek diperoleh dengan menghitung selisih jarak dari frame satu ke frame selanjutnya. Tabel 1 menunjukkan jarak perpindahan objek disetiap frame. Pada tabel 1 , satuan jarak yang digunakan adalah satuan meter. 


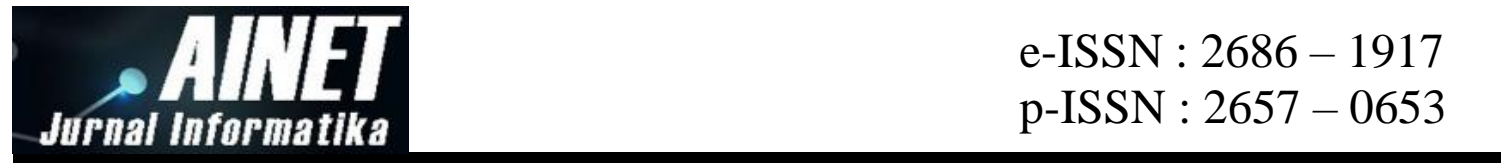

Tabel 1. Jarak perpindahan objek kendaraan disetiap frame

\begin{tabular}{|c|c|c|c|}
\hline No & Frame & $\begin{array}{l}\text { Jarak } \\
(\mathrm{m})\end{array}$ & $\begin{array}{c}\text { Jarak } \\
\text { Perpindahan (m) }\end{array}$ \\
\hline 1 & frame 1 & 41.5079 & 0 \\
\hline 2 & frame 2 & 39.3671 & 2.1408 \\
\hline 3 & frame 3 & 37.1996 & 2.1675 \\
\hline 4 & frame 4 & 34.8433 & 2.3563 \\
\hline 5 & frame 5 & 32.5793 & 2.264 \\
\hline 6 & frame 6 & 30.2699 & 2.3094 \\
\hline 7 & frame 7 & 27.9858 & 2.2814 \\
\hline 8 & frame 8 & 25.5538 & 2.432 \\
\hline 9 & frame 9 & 23.2093 & 2.3445 \\
\hline 10 & frame 10 & 20.7744 & 2.4349 \\
\hline 11 & frame 11 & 19.9014 & 0.873 \\
\hline 12 & frame 12 & 18.9018 & 0.9996 \\
\hline 13 & frame 13 & 17.8187 & 1.0831 \\
\hline 14 & frame 14 & 16.7423 & 1.0764 \\
\hline 15 & frame 15 & 15.9172 & 0.8251 \\
\hline 16 & frame 16 & 15.1209 & 0.7963 \\
\hline 17 & frame 17 & 14.4328 & 0.6881 \\
\hline 18 & frame 18 & 13.7993 & 0.6335 \\
\hline
\end{tabular}

Terlihat bahwa jarak objek pada frame 1 lebih besar dibandingkan dengan frame selanjutnya. Hal ini terjadi karena pada frame 1, objek berada jauh dari titik letak kamera dan semakin tinggi jumlah frame maka semakin dekat jarak objek. Jarak perpindahan objek pada frame 1 bernilai 0 karena pada pada frame 1 objek baru terdeteksi sehingga belum memiliki selisih dengan frame sebelumnya. Objek tidak bergerak secara konstan sehingga jarak perpindahan objek disetiap frame bervariasi.

Hasil penelitian menunjukkan bahwa metode GMM bisa diterapkan untuk mendeteksi objek bergerak dalam video dengan memisahkan objek foreground dan background. Selain digunakan untuk menghitung jarak objek disetiap frame, deteksi objek menggunakan GMM juga dapat diterapkan untuk menghitung jumlah kendaraan dalam video. Dibutuhkan analisa blob dan pembatasan area ROI yang tepat agar mendapatkan hasil deteksi yang baik dalam menggunakan metode GMM [7]. Dilakukan pelacakan objek untuk mengetahui bahwa objek yang terdeteksi di frame 1 sama dengan frame selanjutnya. Pelacakan objek dilakukan menggunaka metode kalman filter. Kalman filter merupakan suatu metode rekursif untuk pelacakan objek [8], [9]. Jarak perpindahan objek yang diperoleh pada penelitian ini digunakan untuk menghitung kecepatan kendaraan dalam video.

\section{Kesimpulan}

Berdasarkan hasil penelitian dapat disimpulkan bahwa metode GMM dapat digunakan untuk deteksi kendaraan dengan membedakan antara objek foreground dan background. 
Diperlukan analisis blob dan penentuan area $\mathrm{ROI}$ yang tepat untuk mendapatkan hasil deteksi yang tepat. Metode proyeksi kamera Pinhole Model dapat diterapkan untuk menghitung jarak objek dalam frame video. Dibutuhkan kalibrasi kamera yang tepat dalam menentukan parameter - parameter yang dibutuhkan untuk menghitung jarak perpindahan objek kendaraan dalam video. Penelitian ini dapat diterapkan untuk pengembangan penelitian selanjutnya yaitu menghitung kecepatan kendaraan dalam video.

\section{Referensi}

[1] B. Indrabayu, A. Achmad, I. Nurtanio, and F. Mayasari, "Blob modification in counting vehicles using gaussian mixture models under heavy traffic," ARPN J. Eng. Appl. Sci., pp. 7157-7163, 2015.

[2] Nirwang and B. Ricky, "Metode Global Contour Shape untuk Menentukan Jumlah Mobil dalam Intelligent Transport System," Univetsitas Hasanuddin, 2013.

[3] Q. Muhammad Farid and I. Chairul, "Metode Histogram of Oriented Gradient (HOG) untuk Menentukan Jumlah Mobil dalam Intelligent Transport System," Universitas Hasanuddin, 2013.

[4] A. Nurhadiyatna et al., "Improved vehicle speed estimation using gaussian mixture model and hole filling algorithm," in 2013 International Conference on Advanced Computer Science and Information Systems (ICACSIS), 2013, pp. 451-456.

[5] R. D. Adityo, E. M. Yuniarno, I. K. E. Purnama, and M. H. Purnomo, "KALIBRASI PARAMETER KAMERA DENGAN PROYEKSI PATERN MENGGUNAKAN PROJECTOR PADA PROSES REKONSTRUKSI 3D BERBASIS STRUCTURED LIGHT," Semantik, vol. 2, no. 1, 2012.

[6] G. W. Wiriasto, H. Arwoko, E. Mulyanto, and A. K. Indrawan, "KALIBRASI KAMERA TUNGGAL MENGGUNAKAN TRANSFORMASI LINIER (DLT)," 2012.

[7] Basri, "Metode Gaussian Mixture Models untuk Optimalisasi Perhitungan Kendaraan dalam Sistem Transportasi Cerdas," Universitas Hasanuddin, 2015.

[8] W. L. Khong, W. Y. Kow, H. T. Tan, H. P. Yoong, and K. T. K. Teo, "Kalman filtering based object tracking in surveillance video system," in Proceedings of the 3rd CUTSE International Conference, 2011, pp. 669-675.

[9] H. S. Parekh, D. G. Thakore, and U. K. Jaliya, "A survey on object detection and tracking methods," Int. J. Innov. Res. Comput. Commun. Eng., vol. 2, no. 2, pp. 2970-2979, 2014. 